\title{
Radiation Therapy for Angiosarcoma of the Scalp: Total Scalp Irradiation and Local Irradiation
}

\author{
MASAHARU HATA \\ Division of Radiation Oncology, Department of Oncology, \\ Yokohama City University Graduate School of Medicine, Yokohama, Japan
}

\begin{abstract}
Angiosarcoma, a rare cutaneous malignancy, frequently arises in the scalp of older individuals. Because it characteristically initially mimics benign disease, such as a bruise, definitive diagnosis in the early stages is difficult. Angiosarcoma of the scalp is highly malignant and often accompanied by lung metastases that cause hemopneumothorax. Although surgery has been the standard and most reliable curative treatment for angiosarcoma of the scalp, there is a high probability of local recurrence, even after wide surgical excision. Therefore, postoperative radiation therapy has been administered in an attempt to minimize local recurrence. However, surgery is contraindicated in many older patients because of severe comorbidities or age. Definitive radiation therapy has been administered to such patients and has achieved good local control. In particular, total scalp irradiation may be a promising option for curative treatment of angiosarcoma of the scalp. Recent reports suggest that chemotherapy, particularly with taxanes, can prolong survival by reducing the rate of distant failure after radiation therapy. Thus, radiation therapy along with chemotherapy is now recommended for curative treatment of patients with inoperable disease and even some patients with operable disease. Technological developments in radiation therapy, such as intensity-modulated radiation therapy, will contribute to enhanced efficacy and reduced toxicities in the treatment of patients with angiosarcoma of the scalp.
\end{abstract}

This article is freely accessible online.

Correspondence to: Masaharu Hata, MD, Division of Radiation Oncology, Department of Oncology, Yokohama City University Graduate School of Medicine, 3-9 Fukuura, Kanazawa-ku, Yokohama, Kanagawa 236-0004, Japan. Tel: +81 457872696, Fax: +81457860369, e-mail: mhata@syd.odn.ne.jp

Key Words: Angiosarcoma, chemotherapy, radiation therapy, scalp, total scalp irradiation, review.
Angiosarcoma, a relatively rare cutaneous malignancy of endothelial cell origin, accounts for around $2 \%$ of soft-tissue sarcomas and 5\% of cutaneous soft-tissue sarcomas (1-3). More than half of all angiosarcomas arise in the head and neck area, particularly in the scalp of older individuals. Cutaneous sarcoma typically presents initially as multifocal reddish or dark purple plaques and thereafter exhibits tumorous growth and infiltration, edema, ulceration, and bleeding. Because it initially resembles benign conditions, such as a bruise or hematoma, diagnosis tends to be delayed, accounting for the reported interval between onset of symptoms and diagnosis of approximately 5 months (4). Angiosarcoma of the scalp is highly malignant, frequently resulting in distant metastasis at an early stage. In particular, lung metastasis occurs in many patients and often causes hemopneumothorax. The prognosis is thus very poor, the 5-year disease-free survival rate being $20 \%$ or less (2-4).

Surgery is the standard and most reliable curative treatment for angiosarcoma of the scalp (1-5). However, there are often multiple, large, and ill-defined lesions in the scalp, and local recurrence occurs at the high rate of $\geq 75 \%$, even after wide surgical excision $(3,6-8)$. Postoperative radiation therapy has been used aggressively to reduce the risk of local recurrence; however, surgery is contraindicated in many patients because of old age or comorbidity. These patients are possible candidates for definitive radiation therapy. The efficacy of chemotherapy with taxanes, such as paclitaxel and docetaxel, has recently been reported and chemoradiotherapy is recommended for curative treatment of angiosarcoma of the scalp, even in some patients with operable disease (8-12). Furthermore, immunotherapy with recombinant interleukin-2 (rIL-2) has been used in a supplementary role, and targeted therapy with molecular agents, such as sorafenib and pazopanib, is now being attempted (13-16).

\section{Radiation Therapy}

Definitive radiation therapy. Curative radiation therapy has recently been administered to medically inoperable patients 
with angiosarcoma of the scalp. However, because there have been few studies, and there are therefore poor data, on definitive radiation therapy for angiosarcoma of the scalp, the optimal radiation regimen remains unclear. We previously reported administering total scalp irradiation with X-rays and electrons (17). Considering the abovementioned high rate of local recurrence in the scalp, total scalp irradiation seems a reasonable option for curative radiation therapy. Accordingly, this continues to be our preferred treatment option. However, there is as yet no evidence that total scalp irradiation achieves better survival than local irradiation. How effectively total scalp irradiation prevents recurrence in sites of the scalp other than that of the primary tumor also remains unknown.

Ohguri et al. reported 20 patients with angiosarcoma of the scalp treated with radiation therapy (18). Five out of these 20 patients underwent surgery before radiation therapy, and two underwent concurrent chemotherapy with paclitaxel along with radiation therapy. All 20 patients also received supplementary rIL-2 immunotherapy during and/or after radiation therapy. The tumor size was $\leq 5 \mathrm{~cm}$ in eight patients and $>5 \mathrm{~cm}$ in 12 . A median total dose of $70.3 \mathrm{~Gy}$ in $2-3 \mathrm{~Gy}$ fractions was delivered locally to the tumor sites. After a median follow-up of 30 months, the local control rate was $65 \%$ and the overall survival rate $50 \%$. Distant metastases were detected in $55 \%$ of all patients.

Suzuki et al. treated 14 patients, including two whose primary tumors were on their faces, with local irradiation (19). The median total dose delivered was $70 \mathrm{~Gy}$ (range=60-100 Gy) in 2-3 Gy fractions. Radiation therapy was used as definitive therapy in 10 patients, preoperatively for one, and postoperatively for three. Chemotherapy with docetaxel was administered to 12 patients during and after radiation therapy. Six patients also underwent additional immunotherapy with rIL-2 before and after radiation therapy. Although 10 patients had multiple tumors and eight had large tumors ( $>5 \mathrm{~cm}$ in diameter), local control was achieved in $71 \%$ of all patients and $64 \%$ had developed no distant metastasis at a median follow-up time of 16 months. The use of chemotherapy may have contributed to the low rate of distant metastasis.

Miki et al. reported the outcomes of 17 patients, including one whose primary tumor was on the face, after treatment of seven patients with total scalp irradiation and 10 with local irradiation (20). A total radiation dose of 70 Gy in 2.0-2.5 Gy fractions was delivered to all patients; however, the dose delivered to the whole scalp was not reported. Three patients had undergone surgery before radiation therapy. Chemotherapy with docetaxel was administered concurrently with radiation therapy in 12 patients and six patients also received supplemental immunotherapy with rIL-2. The local control and distant metastasis-free rates were $53 \%$ and $47 \%$, respectively, after a median follow-up of 18 months. The median survival time was 26 months. Unfortunately, detailed data concerning failure patterns, for instance, within or outside of the local radiation field of the scalp, were not reported.

To the best of our knowledge, with the exception of case reports, there have been no reports on definitive radiation therapy for angiosarcoma of the scalp alone, including the above-mentioned reports. Although previous studies have presented the outcomes of radiation therapy for angiosarcoma of the scalp, all of these series involved more than a few patients with tumors in other primary sites, including the face, body trunk, and extremities, and/or who had undergone surgery prior to radiation therapy $(3,8,9$, $11,12,21-23)$. Therefore, it is very difficult to determine the true efficacy of definitive radiation therapy for angiosarcoma of the scalp. These previous studies are shown in Table I. For this reason, we previously published a retrospective series of patients with angiosarcoma of the scalp alone who had received only definitive radiation therapy; this series did not include patients treated with adjuvant radiation therapy after surgery (17). In that series, 17 patients received total scalp irradiation with $\mathrm{X}$-rays and electrons with a median dose of $50 \mathrm{~Gy}$ in 25 fractions followed by a local radiation boost with a median dose of $20 \mathrm{~Gy}$ in 10 fractions so that a median total dose of $70 \mathrm{~Gy}$ in 35 fractions was delivered to the primary tumors. The radiation fields and dose distribution curves of a typical patient are shown in Figures 1 and 2. A bolus with a 5-10 mm water-equivalent thickness was used to compensate for the surface dose to the tumor and scalp. All 17 patients received supplementary rIL-2 immunotherapy with the aim of enhancing efficacy of tumor control. Four patients also received chemotherapy, mainly with docetaxel. This treatment achieved a better local control rate $(86 \%$ at 3 years) than previous studies (Figure 3) $(3,8,11,12,18-22)$. The primary tumors of two patients who had presented with invasion of the skull and temporal muscle and received a total dose of $70 \mathrm{~Gy}$ in 35 fractions progressed after radiation therapy. Thus, a total dose of $70 \mathrm{~Gy}$ in conventional fractions may be insufficient to eradicate a locally advanced, deeply invasive tumor. Additionally, although most primary tumors were controlled, distant failure occurred in many patients (84\% at 3 years) and the 3-year overall survival rate of all patients was only $23 \%$. The high distant failure rate and poor overall survival may be because only a few patients in our study received chemotherapy.

Regarding therapy-related toxicities, radiation dermatitis of the scalp and alopecia are sure to occur as acute reactions in all patients. Some patients develop grade 3 radiation dermatitis, which is usually transient and easily manageable by conservative treatment. Severe acute toxicities, such as incurable skin ulcer or necrosis requiring dermatoplasty, are rare. Provided that careful consideration is given to the 
Hata: Radiotherapy for Angiosarcoma of the Scalp (Review)

Table I. Previous reports of radiation therapy for angiosarcoma of the scalp.

\begin{tabular}{|c|c|c|c|c|c|c|c|c|c|c|c|}
\hline $\begin{array}{l}\text { Author, } \\
\text { year } \\
\text { (ref.) }\end{array}$ & $\begin{array}{c}\text { No. } \\
\text { of } \\
\text { patients }\end{array}$ & $\begin{array}{l}\text { Primary } \\
\text { tumor } \\
\text { site }\end{array}$ & Surgery & $\begin{array}{l}\text { Chemo- } \\
\text { therapy }\end{array}$ & $\begin{array}{l}\text { Immuno- } \\
\text { therapy }\end{array}$ & $\begin{array}{l}\text { Tumor } \\
\text { size }\end{array}$ & $\begin{array}{l}\text { Radiation } \\
\text { field }\end{array}$ & $\begin{array}{l}\text { Total dose/ } \\
\text { fraction size } \\
\text { (median, Gy) }\end{array}$ & $\begin{array}{l}\text { Local } \\
\text { control } \\
\text { rate }\end{array}$ & $\begin{array}{c}\text { Distant } \\
\text { failure-free } \\
\text { rate }\end{array}$ & $\begin{array}{l}\text { Overall } \\
\text { survival } \\
\text { rate }\end{array}$ \\
\hline $\begin{array}{l}\text { Morrison } \\
\text { et al., } 1995 \\
\text { (23) }\end{array}$ & 14 & $\begin{array}{l}\text { Scalp: } 11 \\
\text { face: } 3\end{array}$ & $\begin{array}{l}\text { Yes: } 7 \\
\text { No: } 7\end{array}$ & $\begin{array}{c}\text { DXR, DTIC, } \\
\text { CPA: } 10 \\
\text { No: } 4\end{array}$ & No: 14 & NA & $\begin{array}{l}\text { TSI: } 9 \\
\text { LI: } 5\end{array}$ & $\begin{array}{c}20-75(63.5) / \\
2.0-2.5\end{array}$ & $\begin{array}{l}\text { MT at RT } \\
\text { Yes: } 55 \% \\
\text { No: } 80 \% \\
\text { (5-year) }\end{array}$ & $\begin{array}{c}37 \% \\
(5-\text {-year })\end{array}$ & $\begin{array}{c}29 \% \\
\text { (5-year) }\end{array}$ \\
\hline $\begin{array}{l}\text { Sasaki et al., } \\
2002 \text { (22) }\end{array}$ & 30 & $\begin{array}{l}\text { Scalp: } 21 \\
\text { face/trunk, } \\
\text { etc.: } 9\end{array}$ & $\begin{array}{l}\text { Yes: } 9 \\
\text { No: } 21\end{array}$ & No: 30 & $\begin{array}{c}\text { rIL-2: } 20 \\
\text { No: } 10\end{array}$ & $\begin{array}{l}\leq 5 \mathrm{~cm}: 14 \\
>5 \mathrm{~cm}: 16\end{array}$ & LI: 30 & $(68) / 1.5-2.0$ & $\begin{array}{c}57 \% \\
(1-y e a r)\end{array}$ & $\begin{array}{c}53 \% \\
\text { (8-month) }\end{array}$ & $\begin{array}{c}37 \% \\
\text { (1-year, CSS) }\end{array}$ \\
\hline $\begin{array}{l}\text { Ward et al., } \\
2003 \text { (21) }\end{array}$ & 19 & $\begin{array}{l}\text { Scalp: } 7 \\
\text { head and neck, } \\
\text { etc.: } 12\end{array}$ & $\begin{array}{l}\text { Yes: } 13 \\
\text { No: } 6\end{array}$ & $\begin{array}{c}\text { DXR, VCR, } \\
\text { CPA: } 2 \\
\text { No: } 17\end{array}$ & No: 19 & $\begin{array}{l}\leq 5 \mathrm{~cm}: 13 \\
>5 \mathrm{~cm}: 6\end{array}$ & LI: 19 & $\begin{array}{c}45-75.6 / 1.8 \\
1.2-1.5 \mathrm{BID} \\
\text { or } 1.0 \mathrm{TID}\end{array}$ & $\begin{array}{c}50 \% \\
\text { (5-year) }\end{array}$ & $\begin{array}{c}47 \% \\
\text { (30-month) }\end{array}$ & $\begin{array}{c}51 \% \\
\text { (5-year) }\end{array}$ \\
\hline $\begin{array}{l}\text { Ohguri et al., } \\
2005 \text { (18) }\end{array}$ & 20 & Scalp: 20 & $\begin{array}{l}\text { Yes: } 5 \\
\text { No: } 15\end{array}$ & $\begin{array}{l}\text { PTX: } 2 \\
\text { No: } 18\end{array}$ & rIL-2: 20 & $\begin{array}{l}<5 \mathrm{~cm}: 8 \\
>5 \mathrm{~cm}: 12\end{array}$ & LI: 20 & $(70.3) / 2.0-3.0$ & $\begin{array}{c}65 \% \\
\text { (30-month) }\end{array}$ & $\begin{array}{c}45 \% \\
\text { (30-month) }\end{array}$ & $\begin{array}{c}50 \% \\
\text { (30-month) }\end{array}$ \\
\hline $\begin{array}{l}\text { Miki, et al., } \\
2013(20)\end{array}$ & 17 & $\begin{array}{l}\text { Scalp: } 16 \\
\text { face: } 1\end{array}$ & $\begin{array}{l}\text { Yes: } 3 \\
\text { No: } 14\end{array}$ & $\begin{array}{l}\text { DTX: } 12 \\
\text { No: } 5\end{array}$ & $\begin{array}{l}\text { rIL-2: } 6 \\
\text { No: } 11\end{array}$ & $\begin{array}{l}<5 \mathrm{~cm}: 2 \\
\geq 5 \mathrm{~cm}: 15\end{array}$ & $\begin{array}{l}\text { TSI: } 7 \\
\text { LI: } 10\end{array}$ & $70 / 2.0-2.5$ & $\begin{array}{c}53 \% \\
\text { (18-month) }\end{array}$ & $\begin{array}{c}47 \% \\
\text { (18-month) }\end{array}$ & $\begin{array}{c}\text { MST } 26 \\
\text { months }\end{array}$ \\
\hline $\begin{array}{l}\text { Fujisawa et al., } \\
2014 \text { (11) }\end{array}$ & , 16 & $\begin{array}{c}\text { Scalp: } 14 \\
\text { lower } \\
\text { extremities: } 2\end{array}$ & No: 16 & $\begin{array}{l}\text { DTX: } 15 \\
\text { PTX: } 1\end{array}$ & $\begin{array}{l}\text { rIL-2: } 4 \\
\text { No: } 12\end{array}$ & $\begin{array}{c}\leq 5 \mathrm{~cm}: 2 \\
>5 \mathrm{~cm}: 14\end{array}$ & NA & $\begin{array}{c}48-80(70) / \\
\text { NA }\end{array}$ & $\begin{array}{c}63 \% \\
\text { (25-month) }\end{array}$ & $\begin{array}{c}56 \% \\
\text { (25-month) }\end{array}$ & $\begin{array}{c}56 \% \\
(3 \text {-year) }\end{array}$ \\
\hline $\begin{array}{l}\text { Hata et al., } \\
2014 \text { (17) }\end{array}$ & 17 & Scalp: 17 & No: 17 & $\begin{array}{l}\text { DXR, } \\
\text { CBDCA: } 1 \\
\text { DTX: } 3 \\
\text { No: } 13\end{array}$ & rIL-2: 17 & $\begin{array}{l}\leq 5 \mathrm{~cm}: 9 \\
>5 \mathrm{~cm}: 8\end{array}$ & TSI: 17 & $\begin{array}{c}60-80(70) / \\
1.8-2.0\end{array}$ & $\begin{array}{c}86 \% \\
(3 \text {-year) }\end{array}$ & $\begin{array}{c}16 \% \\
\text { (3-year) }\end{array}$ & $\begin{array}{c}23 \% \\
(3 \text {-year) }\end{array}$ \\
\hline $\begin{array}{l}\text { Suzuki et al., } \\
2016 \text { (19) }\end{array}$ & 14 & $\begin{array}{l}\text { Scalp: } 12 \\
\text { face: } 2\end{array}$ & $\begin{array}{l}\text { Yes: } 4 \\
\text { No: } 10\end{array}$ & $\begin{array}{l}\text { DTX: } 12 \\
\text { No: } 2\end{array}$ & $\begin{array}{l}\text { rIL-2: } 6 \\
\text { No: } 8\end{array}$ & $\begin{array}{l}\leq 5 \mathrm{~cm}: 8 \\
>5 \mathrm{~cm}: 6\end{array}$ & LI: 14 & $\begin{array}{c}60-100(70) / \\
2.0-3.0\end{array}$ & $\begin{array}{c}71 \% \\
(1-\text { year })\end{array}$ & $\begin{array}{c}64 \% \\
\text { (16-month) }\end{array}$ & $\begin{array}{c}83 \% \\
\text { (1-year) }\end{array}$ \\
\hline
\end{tabular}

DXR, Doxorubicin; DTIC, dacarbazine; CPA, cyclophosphamide; rIL-2, recombinant interleukin-2; VCR, vincristine; PTX, paclitaxel; DTX, docetaxel; CBDCA, carboplatin; NA, not available; TSI, total scalp irradiation; LI, local irradiation; MT, macroscopic tumor; RT, radiation therapy; BID, twice daily; TID, three times daily; CSS, cause-specific survival; MST, median survival time.

irradiated dose and volume administered to organs at risk severe late toxicities, such as osteomyelitis or necrosis of the skull and brain necrosis, are also uncommon. In our study, there were no grade 3 or more acute or late toxicities and the planned treatment was safely completed in all patients (17).

To summarize the results of previous studies, radiation therapy with a median total dose of approximately $70 \mathrm{~Gy}$ results in a local control rate of $\geq 50 \%(12,17-22)$. At this stage, the optimal radiation dose is unclear because of poor data; however, higher dose irradiation at $>70$ Gy may lead to better local tumor control, particularly of locally advanced tumors. It also remains unknown which radiation field (total scalp or local site) is preferable for initial irradiation. Further detailed analyses of pattern failures in the scalp following radiation therapy may provide an answer to this question. Almost half of patients develop distant failure after radiation therapy regardless of primary tumor control $(11,12,17-23)$. Data from previous studies suggest that administration of chemotherapy, with taxanes as the main agent, along with radiation therapy improves prognosis; however, a standard regimen, including the types of chemotherapeutic agents, doses, and timing has not yet been established $(8,9,11,12,20)$. Chemotherapy combined with radiation therapy is surely essential for prolonging survival and maximizing cure.

Postoperative radiation therapy. Surgical excision is currently the curative treatment of choice for patients with resectable angiosarcoma of the scalp. However, even when tumors have been completely resected with wide surgical excision, local control rates are exceedingly poor at $\leq 25 \%$ $(3,6-8)$. Therefore, postoperative radiation therapy has been used to minimize local recurrence. Although there have been no randomized controlled trials comparing the outcomes of surgery alone and surgery followed by postoperative radiation therapy for angiosarcoma of the scalp, some retrospective studies have found that postoperative radiation therapy reduces the risk of local recurrence and improves survival $(4,8,24)$.

Guadagnolo et al. reported on results of treatment of patients with angiosarcoma of the scalp or face/ear. Twenty patients were treated with surgery alone and 23 with surgery and radiation therapy. All but one of the 23 


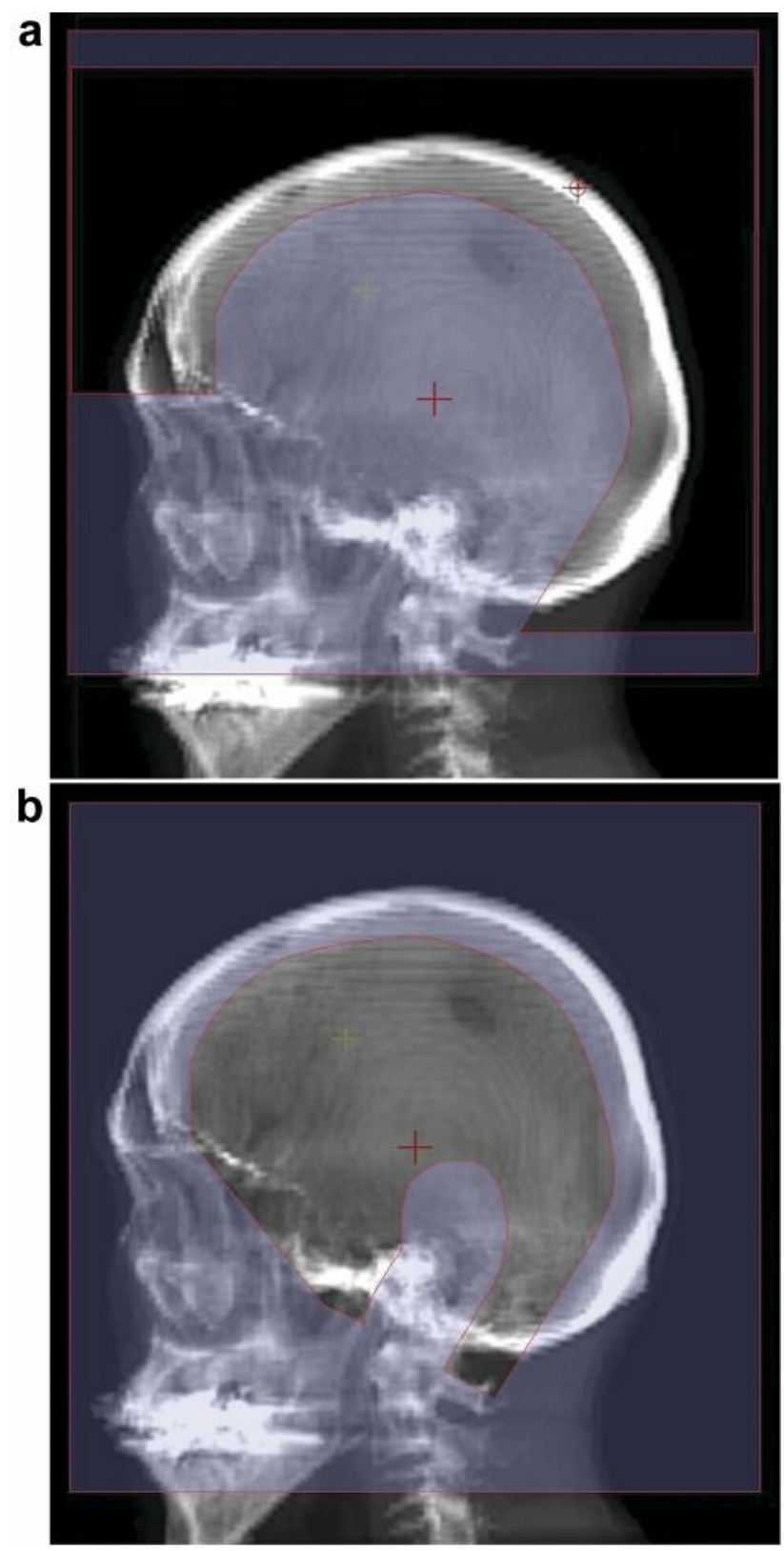

Figure 1. The radiation fields of $X$-rays (a) and electrons (b) created with digitally reconstructed radiographs in the 3-dimensional planning of radiation therapy for a patient with angiosarcoma of the scalp. Six $M V X$-rays are delivered to the central scalp through bilaterally opposed ports and $8 \mathrm{MeV}$ electrons to the temporal scalp bilaterally through single ports. All X-ray and electron fields share the same central axis. The radiation fields for both $X$-rays and electrons are shaped with a low melting-point lead block.

patients received postoperative radiation therapy with a median total dose of 60 Gy (range, 60-70 Gy) in 2 Gy fractions to tumor sites using photons or electrons (8). The local control rates at 5 years were $25 \%$ in the surgery a

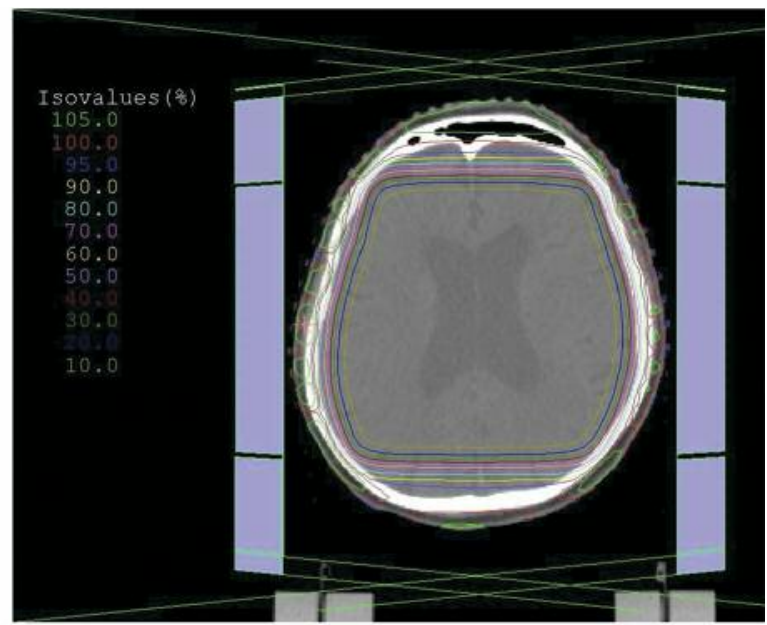

b

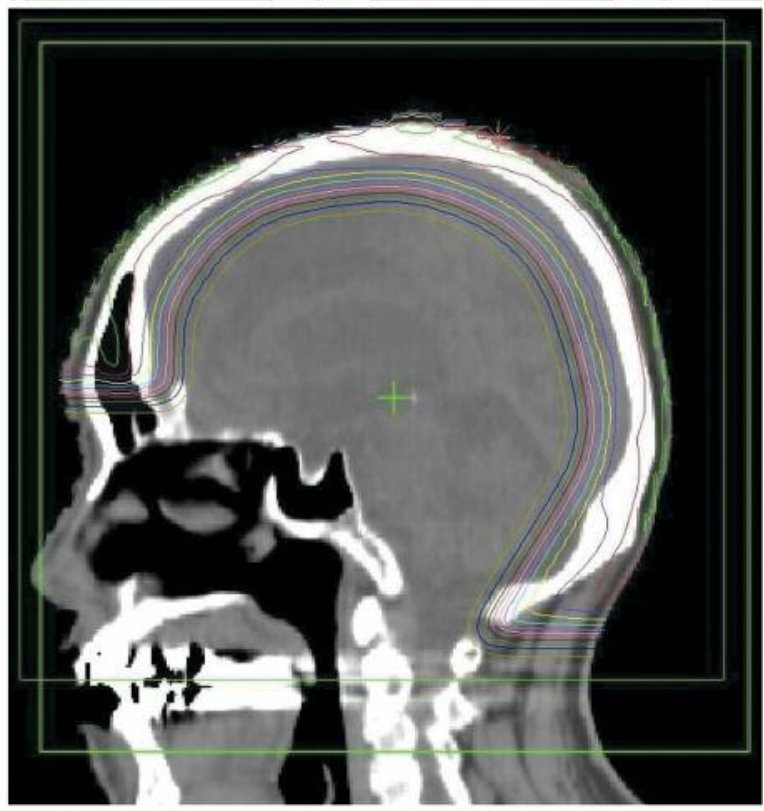

Figure 2. Dose distribution curves on axial (a) and sagittal (b) computed tomography images in radiation therapy planning. The radiation dose is adjusted so that the whole scalp, involving the junction of the X-ray and electron fields, is included within the 90-110\% prescribed dose.

alone group and $84 \%$ in the surgery and radiation therapy group; this difference was significant. There was also a significant difference in the 5 -year overall survival rates between the surgery alone group (40\%) and the combined therapy group (68\%).

Pawlik et al. performed wide surgical excision in 28 patients with angiosarcoma of the scalp, 23 of whom underwent surgery and postoperative radiation therapy and five surgery alone (4). Total scalp irradiation with a total dose of $60 \mathrm{~Gy}$ in 1.8-2.0 Gy fractions was used to treat potential microscopic disease. At a median follow-up of 18 
a

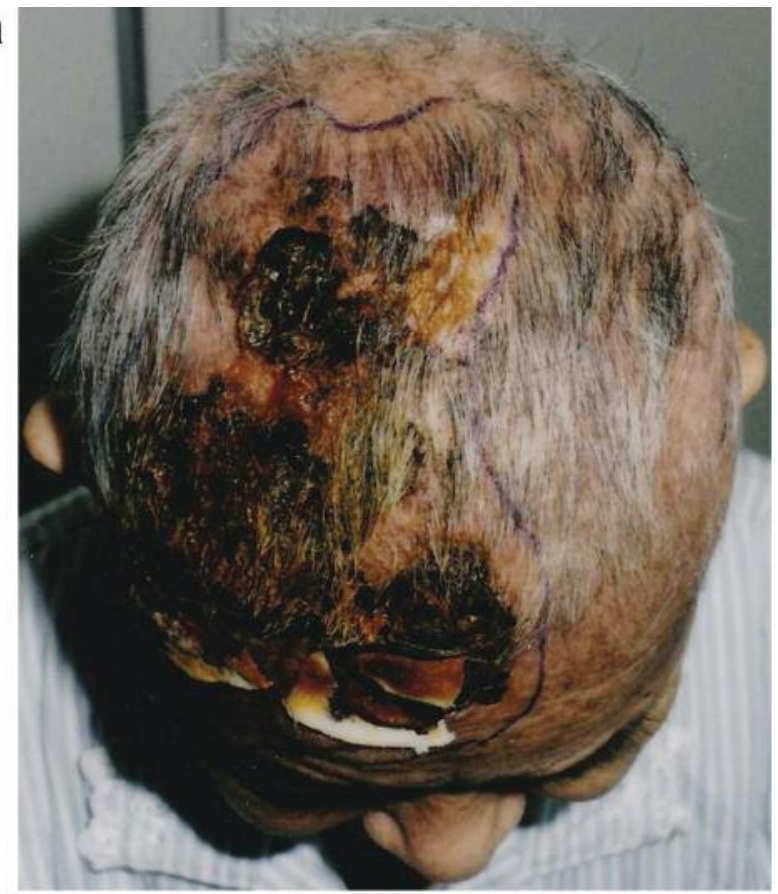

b

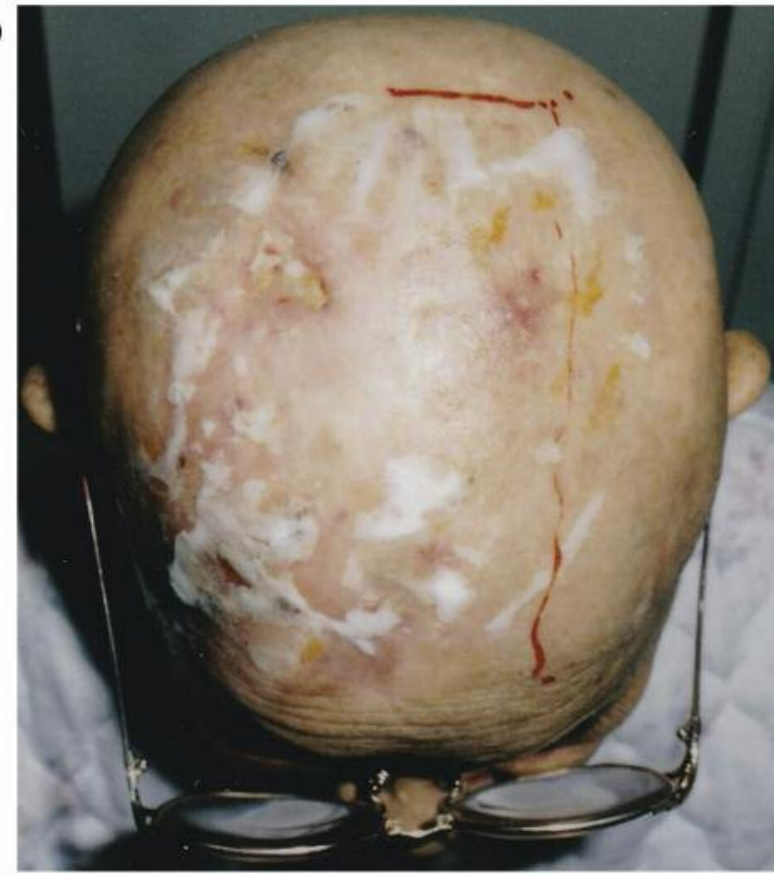

Figure 3. Photographs of the primary tumor site before (a) and after (b) radiation therapy in a patient with diffusely-spread dark purple angiosarcoma in the right front-parietal region of the scalp. Almost all tumors disappeared.

months, 17 patients had developed local recurrence. Although the outcomes were not reported in detail, radiation therapy significantly prolonged time to local recurrence. Furthermore, patients who had received postoperative radiation therapy had an almost 4-fold longer median survival time than patients who did not.

Mark et al. presented the treatment outcomes of 67 patients, more than half of whom had primary tumors not on the scalp, but on the extremities or trunk (24). Twenty-three patients were treated with surgery alone and 12 with a combination of surgery and radiation therapy. These patients were followed up for a median of 30 months after treatment. Local recurrences were detected in $83 \%$ of the surgery alone group and $25 \%$ of the surgery and radiation therapy group; this difference was significant. In addition, there was a significant difference in 5-year disease-free survival rates between patients who underwent surgery without radiation therapy (17\%) versus those with radiation therapy (43\%).

These outcomes indicate that radiation therapy following surgery is effective. Adjuvant radiation therapy after curative surgery for angiosarcoma of the scalp appears promising and is strongly recommended for improving local control and prognosis.

\section{Future Prospects}

When total scalp irradiation is delivered with the conventional technique of three-dimensional conformal radiation therapy using a widely employed linear accelerator, a combination of X-rays and electrons, as used in our study, or electrons alone, has been used (4, 8, 17, 20, $23,25-27)$. This treatment has the advantage that it is straightforward to plan and administer; however, the dose distribution at the junction of the radiation fields will likely be inhomogeneous. In an attempt to address this problem, the advanced technique of intensity-modulated radiation therapy (IMRT) is currently being utilized for total scalp irradiation in some institutions. In particular, some clinical studies concerning helical tomotherapy and rotational IMRT, typified by volume-modulated radiation therapy, have reported an excellent dose distribution that is homogeneous over the whole scalp while reducing the irradiated dose and volume given to organs at risk, such as the central nervous system (28-30). Although insufficient clinical data on patients treated with such advanced techniques have thus far been collected, these are novel and promising tools for total scalp irradiation. As stated above, angiosarcoma of the scalp is generally treated with external irradiation; however, there are some reports on patients treated with brachytherapy $(31,32)$.

\section{Conclusion}

Angiosarcoma of the scalp is never radioresistant, all previous studies reporting some local control with this treatment modality. However, distant failure frequently occurs after radiation therapy. Reducing the rate of distant failure is 
fundamental to improving patient survival. Recent studies have shown that chemotherapy, particularly with taxanes, is effective in preventing distant failure and contributes to prolonged survival. The clinical use of advanced radiation techniques, such as IMRT, along with chemotherapy to treat patients with angiosarcoma of the scalp will result in enhanced efficacy and reduced toxicities and improve survival by decreasing the rate of distant failure.

\section{Conflict of Interest}

The Author has declared that no actual or potential conflicts of interest exist in regard to this study.

\section{References}

1 Young RJ, Brown NJ, Reed MW, Hughes D and Woll PJ: Angiosarcoma. Lancet Oncol 11: 983-991, 2010.

2 Mendenhall WM, Mendenhall CM, Werning JW, Reith JD and Mendenhall NP: Cutaneous angiosarcoma. Am J Clin Oncol 29: 524-528, 2006.

3 Patel SH, Hayden RE, Hinni ML, Wong WW, Foote RL, Milani S, Wu Q, Ko SJ and Halyard MY: Angiosarcoma of the scalp and face: the Mayo Clinic experience. JAMA Otolaryngol Head Neck Surg 141: 335-440, 2015.

4 Pawlik TM, Paulino AF, McGinn CJ, Baker LH, Cohen DS, Morris JS, Rees R and Sondak VK: Cutaneous angiosarcoma of the scalp: a multidisciplinary approach. Cancer 98: 1716-1726, 2003.

5 NCCN Clinical Practice Guidelines in Oncology. Soft tissue sarcoma version 2.2017. https://www.nccn.org/professionals/ physician_gls/PDF/sarcoma.pdf. Accessed in December 5, 2017.

6 Köhler HF, Neves RI, Brechtbühl ER, Mattos Granja NV, Ikeda MK and Kowalski LP: Cutaneous angiosarcoma of the head and neck: report of 23 cases from a single institution. Otolaryngol Head Neck Surg 139: 519-524, 2008.

7 Buschmann A, Lehnhardt M, Toman N, Preiler P, Salakdeh MS and Muehlberger T: Surgical treatment of angiosarcoma of the scalp: less is more. Ann Plast Surg 61: 399-403, 2008.

8 Guadagnolo BA, Zagars GK, Araujo D, Ravi V, Shellenberger TD and Sturgis EM: Outcomes after definitive treatment for cutaneous angiosarcoma of the face and scalp. Head Neck 33: 661-667, 2011.

9 Hwang K, Kim MY and Lee SH: Recommendations for therapeutic decisions of angiosarcoma of the scalp and face. $J$ Craniofac Surg 26: e253-e256, 2015.

10 Letsa I, Benson C, Al-Muderis O and Judson I: Angiosarcoma of the face and scalp: effective systemic treatment in the older patient. J Geriatr Oncol 5: 276-280, 2014.

11 Fujisawa Y, Yoshino K, Kadono T, Miyagawa T, Nakamura Y and Fujimoto M: Chemoradiotherapy with taxane is superior to conventional surgery and radiotherapy in the management of cutaneous angiosarcoma: a multicentre, retrospective study. $\mathrm{Br}$ J Dermatol 171: 1493-1500, 2014.

12 Ogawa K, Takahashi K, Asato Y, Yamamoto Y, Taira K, Matori S, Iraha S, Yagi N, Yogi A, Haranaga S, Fujita J, Uezato H and Murayama S: Treatment and prognosis of angiosarcoma of the scalp and face: a retrospective analysis of 48 patients. $\mathrm{Br} \mathrm{J}$ Radiol 85: e1127-e1133, 2012.
13 Gebhardt C, Ziegler B, Stadler S, Goerdt S and Utikal J: Complete remission of treatment-refractory advanced angiosarcoma of the scalp by protracted intralesional interleukin2 therapy. Br J Dermatol 172: 1156-1158, 2015.

14 Maki RG, D'Adamo DR, Keohan ML, Saulle M, Schuetze SM, Undevia SD, Livingston MB, Cooney MM, Hensley ML, Mita $\mathrm{MM}$, Takimoto $\mathrm{CH}$, Kraft AS, Elias AD, Brockstein $\mathrm{B}$, Blachère NE, Edgar MA, Schwartz LH, Qin LX, Antonescu CR and Schwartz GK: Phase II study of sorafenib in patients with metastatic or recurrent sarcomas. J Clin Oncol 27: 3133-3140, 2009.

15 van der Graaf WT, Blay JY, Chawla SP, Kim DW, Bui-Nguyen B, Casali PG, Schöffski P, Aglietta M, Staddon AP, Beppu Y, Le Cesne A, Gelderblom H, Judson IR, Araki N, Ouali M, Marreaud S, Hodge R, Dewji MR, Coens C, Demetri GD, Fletcher CD, Dei Tos AP and Hohenberger P; EORTC Soft Tissue and Bone Sarcoma Group; PALETTE study group: Pazopanib for metastatic soft-tissue sarcoma (PALETTE): a randomised, double-blind, placebo-controlled phase 3 trial. Lancet 379: 1879-1886, 2012.

16 Tomita H, Koike Y, Asai M, Ogawa F, Abe K, Tanioka M and Utani A: Angiosarcoma of the scalp successfully treated with pazopanib. J Am Acad Dermatol 70: e19-e21, 2014.

17 Hata M, Wada H, Ogino I, Omura M, Koike I, Tayama Y, Odagiri $\mathrm{K}$, Kasuya $\mathrm{T}$ and Inoue T: Radiation therapy for angiosarcoma of the scalp: treatment outcomes of total scalp irradiation with Xrays and electrons. Strahlenther Onkol 190: 899-904, 2014.

18 Ohguri $\mathrm{T}$, Imada $\mathrm{H}$, Nomoto $\mathrm{S}$, Yahara $\mathrm{K}$, Hisaoka $\mathrm{M}$, Hashimoto H, Tokura Y, Nakamura K, Shioyama Y, Honda H, Terashima H, Moroi Y, Furue M and Korogi Y: Angiosarcoma of the scalp treated with curative radiotherapy plus recombinant interleukin-2 immunotherapy. Int J Radiat Oncol Biol Phys 61: 1446-1453, 2005.

19 Suzuki G, Yamazaki H, Takenaka H, Aibe N, Masui K, Kimoto T, Tatekawa K, Nakashima A, Takenaka T, Asai J, Komori S, Wada M, Katoh N and Yamada K: Definitive radiation therapy for angiosarcoma of the face and scalp. In Vivo 30: 921-926, 2016.

20 Miki Y, Tada T, Kamo R, Hosono MN, Tamiya H, Shimatani Y, Tsutsumi S, Ogino R and Miki Y: Single institutional experience of the treatment of angiosarcoma of the face and scalp. Br J Radiol 86: 20130439, 2013.

21 Ward JR, Feigenberg SJ, Mendenhall NP, Marcus RB Jr. and Mendenhall WM: Radiation therapy for angiosarcoma. Head Neck 25: 873-878, 2003.

22 Sasaki R, Soejima T, Kishi K, Imajo Y, Hirota S, Kamikonya N, Murakami M, Kawabe T, Ejima Y, Matsumoto A and Sugimura $\mathrm{K}$ : Angiosarcoma treated with radiotherapy: impact of tumor type and size on outcome. Int J Radiat Oncol Biol Phys 52: 1032-1040, 2002.

23 Morrison WH, Byers RM, Garden AS, Evans HL, Ang KK and Peters LJ: Cutaneous angiosarcoma of the head and neck. A therapeutic dilemma. Cancer 76: 319-327, 1995.

24 Mark RJ, Poen JC, Tran LM, Fu YS and Juillard GF: Angiosarcoma. A report of 67 patients and a review of the literature. Cancer 77: 2400-2406, 1996.

25 Tung SS, Shiu AS, Starkschall G, Morrison WH and Hogstrom KR: Dosimetric evaluation of total scalp irradiation using a lateral electron-photon technique. Int J Radiat Oncol Biol Phys 27: 153-160, 1993

26 Able CM, Mills MD, McNeese MD and Hogstrom KR: Evaluation of a total scalp electron irradiation technique. Int $\mathrm{J}$ Radiat Oncol Biol Phys 21: 1063-1072, 1991. 
27 Hata M: Radiation therapy for angiosarcoma of the scalp. Total scalp irradiation with X-rays and electrons. Jpn J Clin Radiol 62: 1797-1804, 2017.

28 Orton N, Jaradat H, Welsh J and Tomé W: Total scalp irradiation using helical tomotherapy. Med Dosim 30: 162-168, 2005.

29 Cuccia F, Figlia V, Palmeri A, Verderame F, Lo Casto A, Mannino $\mathrm{M}$ and Ferrera G: Helical Tomotherapy ${ }^{\circledR}$ is a safe and feasible technique for total scalp irradiation. Rare Tumors 9: 6942, 2017

30 Ostheimer C, Hübsch P, Janich M, Gerlach R and Vordermark D: Dosimetric comparison of intensity-modulated radiotherapy (IMRT) and volumetric modulated arc therapy (VMAT) in total scalp irradiation: a single institutional experience. Radiat Oncol J 34: 313-321, 2016.
31 Sanada T, Nakayama H, Irisawa R, Okubo M, Tsuboi R and Tokuuye K: Clinical outcome and dose-volume evaluation in patients who undergo brachytherapy for angiosarcoma of the scalp and face. Mol Clin Oncol 6: 334-340, 2017.

32 Wittych J, Banatkiewicz P, Wachowicz M, Pruska-Pich D, Mitura S and Gisterek I: Angiosarcoma of the scalp: a case report. J Contemp Brachytherapy 6: 208-212, 2014.

Received December 5, 2017

Revised January 10, 2018

Accepted January 11, 2018 